\title{
DEVELOPING CAPACITIES FOR DISASTER RISK REDUCTION IN THE BUILT ENVIRONMENT: CAPACITY ANALYSIS IN SRI LANKA
}

\author{
Kanchana GINIGE ${ }^{1}$, Dilanthi AMARATUNGA ${ }^{2}$ and Richard HAIGH ${ }^{3}$ \\ ${ }^{1}$ School of the Built Environment, $4^{\text {th }}$ Floor, Maxwell Building, The University of Salford, \\ Salford, M5 4WT, UK \\ E-mail: K.N.Ginige@pgr.salford.ac.uk \\ ${ }^{2}$ School of the Built Environment, The University of Salford, UK \\ E-mail: R.D.G. Amaratunga@salford.ac.uk \\ ${ }^{3}$ School of the Built Environment, The University of Salford, UK \\ E-mail: R.P.Haigh@salford.ac.uk
}

Received 16 August 2010; accepted 30 October 2010

\begin{abstract}
This paper introduces a framework for capacity development for disaster risk reduction in the built environment. The framework was developed as a part of an ongoing research which aims to strengthen the capacities of individuals and institutions in the built environment to ensure that disaster risk reduction meets its mission and goals in a sustainable way. It is presented as a matrix that identifies four stages of capacity development against six groups of stakeholders in the built environment. The stages and the stakeholder groups were derived through a series of expert interviews and a comprehensive literature review. The four stages are named as Analysis, Creation, Utilisation and Retention. This paper in its latter sections focuses on the first stage, Analysis, and presents some of the initial findings of the research. Analysis attempts to capture capacity gaps in the relevant context in order to identify required capacity development. The study reviews literature on Sri Lanka and discusses such capacity gaps. Problems in the regulatory structure, deficiencies in necessary laws and regulations including problems in their implementation, and lack of required resources and skills have been identified as the major capacity gaps in the country.
\end{abstract}

KEYWORDS: Built environment; Capacity development framework; Capacity gaps; Disaster risk reduction; Sri Lanka

\section{INTRODUCTION}

\subsection{Background}

Recent natural and human-induced disasters have highlighted the fragility of the built environment and its vulnerability to hazards (Bosher et al., 2007a). The built environment is enormously linked with the everyday life of humans since it provides buildings for all human activities, and infrastructure for all the services that they require. It is the substantial physical framework for human society to function in its many aspects-social, economic, political, and institutional (Geis, 2000). Due to the strong linkages between the built environment and the human society, any destruction to the built environment disturbs the regular functioning of the human society. Thus, the massive destruction caused to the built environment by natural and man- made hazards is an enormous barrier for the human society and its social and economic development. 
In this context, it is extremely important to achieve disaster risk reduction within the built environment to increase its resilience to disasters. Disaster risk reduction is defined as the concept and practice of reducing disaster risks through systematic efforts to analyse and manage the causal factors of disasters, including through reduced exposure to hazards, lessened vulnerability of people and property, wise management of land and the environment, and improved preparedness for adverse events (UN/ISDR, 2009). Hence, disaster risk reduction in the built environment in particular mainly involves reducing exposure of buildings and infrastructure to hazards and minimising their vulnerability through proper land use planning, hazard resistant construction and improved preparedness.

Disasters on the other hand are viewed as results of hazards intersecting with the vulnerabilities of the built environment since the intensity of a disaster is mainly determined by the destruction of the built environment. According to UNDP (cited Duque, 2005), disasters are not the necessary result of hazards but occur only when these hazards intersect with the built environment, particularly poorly located and poorly constructed development. Thus, the vulnerabilities, which increase the risk of disasters and cause destruction, are the characteristics of the built environment that are inadequately capable of resisting the impacts of hazards. In particular, they are the problems incorporated with land use planning, hazard resistant construction and disaster preparedness of the built environment. According to Mileti (1999), the ability of the built environment to withstand the impacts of hazards plays a direct role in determining the casualties and monetary costs of disasters. Therefore, it is important to eliminate the aforementioned problems to achieve disaster risk reduction. In other words, it is the characteristics of the built environment that should be changed and managed to minimise disaster damages since hazards are typically inevitable (Duque, 2005).

Proper land use planning, hazard resistant construction and improved preparedness in the built environment are initiated and implemented by a combination of various aspects such as skills, knowledge, resources, institutions and policies. Notably, they require good governance, proper institutional structures, proper land use planning policies and construction standards, professionals with disaster risk reduction knowledge, a workforce with required construction skills, state of art technology and finance for their creation and maintenance. These aspects are the capacities that drive the built environment towards disaster risk reduction. Further, these capacities are brought into the built environment by different stakeholders, who have an involvement or interest in the projects and processes such as government, community, professionals, skilled and non-skilled workers in the built environment and private sector businesses.

In this context, a framework has been developed by the authors with the aim of strengthening the knowledge, abilities, skills and behaviour of individuals responsible for the built environment, and improving institutional structures and processes to ensure that disaster risk reduction meets its mission and goals in a sustainable way. According to Ginige et al. (2009), capacity development within different sectors such as governments, institutions and communities enables to identify constraints and to plan and manage construction activities of the built environment effectively, efficiently and sustainably. The framework consists of four stages of capacity development, namely, analysis, creation, utilisation and retention against six major stakeholder groups who are involved in the built environment. They are national and local government, International community, Community, Civic society, Private and corporate sector, and Academia and professional associations. 


\subsection{Aim and objectives}

This paper aims to present the aforementioned framework which was developed for capacity development for disaster risk reduction in the built environment. In addition, the paper attempts to demonstrate an overview of capacities and capacity gaps in disaster risk reduction in the built environment. The framework identifies that the process of capacity development begins with identifying existing capacity gaps in the built environment. Identification of existing gaps is critical in recognising what capacities need to be developed. In this regard, this research further studies the built environment in Sri Lanka to identify such capacity gaps. The paper gives an account of disaster risk reduction related capacity gaps in the Sri Lankan built environment with possible means of addressing the identified gaps.

\subsection{Methods}

The framework was mainly developed based on expert opinions of various parties who are involved in the built environment such as built environment professionals, disaster management experts and policy makers in several different countries. Their opinions on the process of capacity development, its different stages and the identification and categorisation of stakeholders who are involved in it were captured through a series of interviews. In addition, a comprehensive literature review on capacity development for disaster risk reduction in the built environment was carried out to inform the framework. In particular, the role of different stakeholders in disaster risk reduction in the built environment was explored through literature.

Firstly, capacity development was identified as a process of four interlinked stages, namely, Analysis, Creation, Utilisation and Retention through the interviews and literature. Secondly, the long list of stakeholders which was identified from the aforementioned methods was grouped into different categories to condense and simplify the framework. Thereafter, the four stages of capacity development were mapped against the stakeholder categories as a matrix to form the framework. The matrix format was suggested since it provided a convenient way of identifying and illustrating, capacity gaps in the Analysis stage and what necessary measures to be taken in the other three stages of capacity development, respective to different stakeholders. The framework, specially the stakeholder categories were refined through an online study, which sought feedback on the framework from a group of experts. As a result, the stakeholders were divided into six broad categories as National and local government, International community, Community, Civic society, Private and corporate sector and Academia and professional associations.

The overview of capacities and capacity gaps in the built environment in relation to disaster risk reduction, and related capacity gaps in Sri Lanka presented in the paper were composed through a literature review.

\section{CAPACITIES AND CAPACITY GAPS IN DISASTER RISK REDUCTION - A GENERAL OVERVIEW}

\subsection{What are capacities?}

Capacities exist in different forms in the world such as knowledge, skills, technology and resources. According to UN/ISDR (2009), capacity is the combination of all the strengths, attributes and resources available within a community, society or an organisation that can be used to achieve agreed goals and they can exist in the forms of infrastructure and physical means, institutions, societal coping abilities, human knowledge, skills, and collective attributes such as social relationships, leadership and management. According to Honadle (1981), ability to anticipate and influence change, make informed and intelligent 
decisions about policy, develop programs to implement policy, attract and absorb resources, manage resources and evaluate current activities to guide future action can be defined as capacity in general.

Apropos, the capacities necessary for effective disaster risk reduction in general could be represented through comprising a society with organisations particularly deal with disaster issues, well-developed disaster plans and preparedness, coping mechanisms, adaptive strategies, memory of past disasters, good governance, ethical standards, local leadership, physical capital, resilient buildings and infrastructure that cope with and resist extreme hazard forces, etc. (Benson et al., 2007). Capacities that are required for post disaster reconstruction are explained here onwards.

\subsection{Capacities for disaster risk reduction in the built environment}

In a study on post tsunami recovery process in Andaman and Nicobar Islands, Gupta and Sharma (2006) state governance, networking between different stakeholders and community based approaches as important elements in post disaster recovery. Good governance is the exercise of economic, political and administrative authority to manage a country's affairs at all levels through bringing together the actions of state, non-state and private sector actors (UNDP, 2004). Therefore, the characteristics of good governance i.e., participation, rule of law, transparency, responsiveness, consensus orientation, equity, effectiveness, efficiency, accountability and strategic vision are essential for a country for its sustainable development and disaster risk reduction (UNDP, 2004). Therefore, the authorities, institutions and plans to manage disaster mitigation and reconstruction activities and coordinate its stakeholders, policy and legislation to regulate disaster mitigation and reconstruction, and human resources to manage the authorities and implement the policies and legislation become necessary capacities for disaster risk reduction under good governance. In this context, governments and local governments have an important role to perform by ensuring all the necessary capacities are in place (UNDP, 2004).

Further, the experience and participation of local and international community are extremely important in disaster mitigation and reconstruction in the built environment. Many studies have recognised the need to include local community's participation into disaster reconstruction (Pardasani, 2006; Owen and Dumashie, 2007; Jayaraj, 2006) since disaster reconstruction is about building back homes and infrastructure to become more resilient to the next disaster, and fit for purpose for the community (Owen and Dumashie, 2007). According to Lawther (2009), involvement of the beneficiaries and the wider community in the re-construction can lead to more sustainable outcomes of projects. The more people are engaged in the process, the greater the level of stakeholder engagement is, the more they are able to influence and take ownership of the outcomes (Lawther, 2009). In this context, knowledge and experience of a local community can input some important information for the construction process such as locations that are less vulnerable to potential disasters, locally available material that can be used for construction, and special community needs that are necessary to be integrated into reconstruction. Incidentally, capacities and experiences of international community in the field of disaster mitigation and reconstruction are vital mainly because, in many developing countries, the lack of knowledge, resources and expertise can be overcome by adequate global cooperation in tackling natural disasters (ElMasri and Tipple, 2002). The supportive role of international agencies can assist countries in disaster mitigation and reconstruction by applying their existing knowledge and resources (El-Masri and Tipple, 2002). 
Incidentally, building codes, land-use planning, environmental risk and human vulnerability monitoring and safety standards are important in improving the design and construction of buildings, agricultural structures, infrastructure and other facilities to reduce their susceptibilities (Nateghi-A, 2000). However, as Nateghi-A (2000) emphasises, building codes, land use policies or design standards are, unlikely to result in more resilient built environment unless the professionals in the built environment who have to implement the codes, standards and policies accept their importance and endorse its use, understand the code and the design criteria required of them and unless the code is fully enforced by authorities checking and penalising designs that do not comply. This highlights the importance of availability of proper human resources in the built environment for disaster mitigation and reconstruction. In this context, education and training are vital in developing necessary human resources. Bosher et al. (2007a) state that risk and hazard training should be systematically integrated into the professional training and professional development of architects, planners, engineers, developers, etc. and it is important to encourage cross disciplinary training for construction professionals and emergency managers (Bosher et al., 2007a). In particular, the following list demonstrates the property and construction skills that can contribute towards disaster mitigation and reconstruction in the built environment (LloydJones, 2006).

- Aiding local government land administration, cadastral mapping.

- Knowledge of land and property legislation, providing support on land rights and claims.

- Knowledge of local regulatory frameworks and ways they could be improved.

- Training and knowledge transfer.

- Disaster risk assessment.
- Links with other built environment professions; inter-disciplinary and team working.

- Contacts with local business and industry; networking.

- Knowledge of appropriate forms of disaster-resistant construction and engineering.

However, it is not only the professional development necessary for the disaster mitigation and reconstruction in the built environment but developing skills and knowledge of non professionals in the built environment such as contractors, construction supervisors, trade workers is vital as well. Having identified the major capacity needs for disaster risk reduction in the built environment, the paper moves to discuss the common capacity gaps in the next section.

\subsection{Capacity gaps in disaster risk reduction in the built environment}

Capacity gaps in the field of disaster management in general are common to disaster mitigation and reconstruction within the built environment as well. Thus the most common capacity gaps in relation to disaster risk reduction can be mentioned as lack of necessary policies and legislation for mitigation and reconstruction, poor implementation of policies and legislation, (Nateghi-A, 2000; Mileti, 1999) problems in disaster management planning structures and coordination of stakeholders (El-Masri and Tipple, 2002), lack of disaster management related awareness, lack of proper education and training, lack of skilled and trained human resources for mitigation and reconstruction, (Bosher et al., 2007b) deficiencies in state of the art technology for disaster mitigation and rapid and sustainable reconstruction, deficiencies in information management (Laverack, 2005), and lack of community involvement in reconstruction (Lawther, 2009). 


\section{CAPACITY DEVELOPMENT FRAMEWORK}

\subsection{Capacity development - the concept}

The process by which people, organisations or society systematically stimulate and develop their capacities over time through improvement of knowledge, skills, systems and institutions is known as capacity development (UN/ISDR, 2009). According to Bolger (2000) the objectives of capacity development are as follows.

- Enhance, or more effectively utilise, skills, abilities and resources.

- Strengthen understandings and relationships.

- Address issues of values, attitudes, motivations and conditions in order to support sustainable development.

Capacity development is seen as a relatively new concept emerged in the 1990s and it is complimentary to some previously introduced ideas in development thinking such as institution building, institutional development, human resources development, development management/ administration and institutional strengthening (Lusthaus et al., 1999). Lusthaus et al. (1999) see this as a concept which links previously isolated approaches to a coherent strategy with a long term perspective and vision of social change. Incidentally, according to UN/ISDR (2009), the concept of capacity development extends the term capacity building to encompass all aspects of creating and sustaining capacity growth over time. Thus, capacity development is a process which runs across several stages. United $\mathrm{Na}$ tions Development Programme introduces five consequent stages in its capacity development process (UNDP, 2008).

- Step 1: Engage stakeholders on capacity development.

- Step 2: Assess capacity assets and needs.
- Step 3: Formulate capacity development response.

- Step 4: Implement a capacity development response.

- Step 5: Evaluate capacity development.

Accordingly, capacity development for disaster risk reduction is referred as creating and sustaining necessary abilities of relevant stakeholders to identify constraints and to plan and manage construction activities in the built environment effectively, efficiently and sustainably in order to reduce damages from disasters. This definition involves both the development of capacities of human resources, institutions, and communities, and also a supportive policy environment. It encompasses the process by which individuals, communities and institutions develop, utilise and retain their skills, abilities and knowledge individually and collectively, to identify their problems and constraints, set mitigation and reconstruction objectives, formulate policies and programs, perform functions required to solve those problems, and achieve a set of mitigation and reconstruction objectives. In this context, a framework has been developed to elaborate the process of capacity development for disaster risk reduction and it is introduced in detail in the subsequent section.

\subsection{Why a framework?}

Developing required capacities for disaster risk reduction is a long and slow process that requires a significant commitment from all stakeholders involved in reconstruction. Thus, the following framework (Figure 1) has been developed to describe this complex process and to develop strategies to enhance necessary capacities in terms of various stakeholder groups who are involved in the process.

The stages of the framework and the groups of stakeholders are explained in detail in the subsequent sections. 


\begin{tabular}{|c|c|c|c|c|c|}
\hline & & \multicolumn{4}{|l|}{ Stages } \\
\hline & & Analysis & Creation & Utilisation & Retention \\
\hline \multirow{6}{*}{ 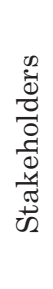 } & National and local governments & & & & \\
\hline & International community & & & & \\
\hline & Community & & & & \\
\hline & Civic society & & & & \\
\hline & Private and corporate sector & & & & \\
\hline & Academia and professional associations & & & & \\
\hline
\end{tabular}

Figure 1. Capacity development framework

\subsection{Analysis, Creation, Utilisation and Retention - the four phases of capacity development}

The horizontal axis of the framework illustrates the stages of capacity development process for disaster risk reduction. Four different stages have been identified in the process as analysis, development, utilisation and retention. These four stages are explained below.

\subsubsection{Analysis}

It is increasingly recognised that the term capacity building is misleading, as building has the undertone of starting something from the beginning, whereas in practice, improving capacity must take account of the current context. One common and problematic theme of capacity development is the individual nature of capacity development interventions. Capacity development is highly influenced by local context and thus is unique in each of its applications. The first stage of capacity enhancement focuses on the analysis of existing capacity, and identification and prioritisation of capacity gaps.

\subsubsection{Creation}

The second stage focuses on the need to create capacity in order to address the identified gaps. Creating capacity requires enormous efforts and time in understanding the local context and finding appropriate means to build capacity. Effective human and institutional capacity rests on a strong foundation that facilitates the creation of new capacities through learning opportunities as well as by putting in place processes that enhance the adaptability required for dealing with a dynamic environment. Such a foundation is created through formal training, informally through on-the-job training, as well as through accumulation of norms, routines and processes, which promote capacity creation on a continuous basis.

\subsubsection{Utilisation}

The third stage considers how developed capacities are mobilised and deployed under realistic conditions. A failure to make effective use of existing capacities can undermine mitigation and reconstruction activities. Efficient and effective use of existing capacities is an important aspect of capacity building as it recognises the need to make use of the affected community's own assets, thereby reducing its sense of helplessness. Making the best use of existing capacities will involve mobilisation of all the creative and innovative capacities that can be found in existing human and institutional capacities.

\subsubsection{Retention}

The final stage addresses the need to retain and sustain capacity over time. Capacity enhancement must be designed in such a way that it is sustainable beyond any initial external intervention. Sustaining capacity is more 
likely to occur in the context of stable political, institutional and economic conditions that provide an atmosphere of support for the capacity building efforts in society. Sources of funding are an important element of sustainability and capacity retention. In the long-run, the key to sustaining capacity will be the availability of local sources of funding. Sustainable capacity building will need to address the capacity to mobilise domestic resources.

\subsection{Stakeholders of disaster risk reduction in the built environment}

In General, stakeholders can be defined as the individuals or organisations that gain or lose from the success or failure of a particular process (Nuseibeh and Easterbrook, 2000). With reference to a project, they may be the individuals or groups who have an interest in the outcomes of the project, who have right or ownership, who contribute through knowledge or support or who are impacted by or can impact the outcomes of a project (Bourne, 2007). In construction, there are different groups and individuals who have a stake in, or expectation of, a project's performance such as clients, project managers, designers, subcontractors, suppliers, funding bodies, users and the community (Newcombe, 2003).In summary, the construction industry involves a wide range of stakeholders, who hold a great variety of interests, concerns, requirements and potential opportunities (Ye et al., 2009). According to Siriwardena et al. (2009), stakeholders of post disaster reconstruction are the groups or individuals who can affect or are affected by the achievement of a reconstruction project's objectives. Thus, it is important to consider the roles of different stakeholders of disaster risk reduction in the built environment since they are the ones who are involved in development and implementation of necessary policies, strategies and practices to minimise vulnerabilities, and who are affected by the success or failure of the process of risk reduction. Accordingly, stakeholders of the process of disaster risk reduction in the built environment have been identified under six broad groups and they are discussed in the subsequent sections.

\subsubsection{National and local government}

Government performs a critical role in development since it has a unique capacity as a mediator between private and public interests and as an actor with local, national and international connections (UNDP, 2004). National and local governments of a country hold the main responsibility for the coordination of different stakeholders at different levels. Coordination among different stakeholders and different levels of authorities such as local, provincial, national and international should be ensured in order to achieve success in disaster management of a country. Government's capability as a mediator and coordinator can facilitate a country by transferring technical know-how and good practice that are useful for integrating disaster risk reduction to the built environment from other countries. Similarly, it can bring finances and other resources to a country through its international relations.

Further, national and local governments of a country have the authority to develop and enforce rules, laws and regulations. In relation to disaster risk reduction in the built environment, governments have administrative and legislative power to enforce regulations and policies on construction operations. Thus, regulating the process of construction to ensure that necessary disaster mitigation and prevention measures are integrated into the practice to reduce disaster risk through enforcement of policy and legislation becomes a duty of national and local government. According to Bosher et al. (2007b), building codes, proper engineering design and construction practices, and land use plans and regulations are critical for disaster mitigation in the built environment. Thus this group of stakeholders is 
defined as public and semi-public entities that have the authority to make and enforce rules, laws and regulations pertaining to the built environment in this categorisation.

\subsubsection{International community}

Non-profit making organisations which possess membership of more than one country and set up as intergovernmental organisations or international non-governmental organisations are considered as the international community under this categorisation. International organisations can be seen in two main types, namely, intergovernmental organisations and international non- governmental organisations (Iriye, 2002). The first type is set up by intergovernmental agreements such as United Nations whilst the second, which are voluntary and open to anyone who wishes to join, is formed by private individuals and groups (Iriye, 2002).

International community also performs a significant role in formulation of policies, guidelines and regulations for disaster risk reduction. International entities such as United Nations International Strategy for Disaster Reduction (UN/ISDR) and United Nations Development Programme (UNDP) are some leading performers in relevant policy making. The policy guidelines such as Hyogo Framework for action and United Nations Millennium Development Goals (MDGs) are globally agreed international agendas for integrating disaster risk reduction for development activities around the world. Thus, international community attempts to bring different nations together to achieve disaster risk reduction under common agendas.

In addition, international community provides necessary assistance for disaster risk reduction for nations in need. Incidentally, capacities and experiences of international community in the field of disaster management are vital mainly because, in many developing countries, the lack of knowledge, resources and expertise can be overcome by adequate global cooperation in tackling natural disasters
(El-Masri and Tipple, 2002). Thus, in the context of disaster risk reduction in the built environment, international community is able to provide necessary skills and knowledge, technology and financial aid.

\subsubsection{Community}

Community is identified as the individuals and groups sharing a natural and built environment that is vulnerable to hazards. In other words, community is the general public; the users and occupants of the built environment and the beneficiaries of disaster risk reduction. Thus, special community needs and concerns require to be necessarily integrated into disaster risk reduction initiatives in the built environment.

According to Lawther (2009), involvement of the beneficiaries and the wider community in the re-construction can lead to more sustainable outcomes of projects. As UN/ISDR states, disaster risk reduction strategies need to build on people's local knowledge and cultural practices, and apply tools and approaches that people can easily understand and integrate into their lives. In particular, members of local communities represent the greatest potential source of local knowledge of hazardous conditions, and are the repositories of traditional coping mechanisms suited to their individual environment (UN/ISDR). Thus, experience and participation of local community are extremely important in disaster risk reduction in the built environment. Their leadership and involvement in the relevant initiatives, and their knowledge and experiences related to the disaster vulnerabilities of the area, safe locations for construction and local resources that can be used for construction are significant in this context.

\subsubsection{Civic society}

This group includes the non-governmental organisations (NGOs) that participate in disaster risk reduction activities, including not-for-profit and voluntary groups that are 
organised on a local, national or international level. These are the voluntary and social organisations that are non state owned who appear for the purposes of disaster risk reduction. The UN/ISDR Secretariat believes that building the resilience of nations and communities to disasters cannot be done without the active participation of NGOs. In this context, UN/ISDR is determined to build a Global Network of NGOs for Community Resilience to Disasters, with the aim of addressing disaster risk reduction issues at sub-national and community levels. UN/ISDR highlights following activities as the most important of NGOs' role in disaster risk reduction.

- NGOs can operate at grassroots level with communities and local organizations as partners, and take a participatory approach to development planning. This allows them to respond better to local people's priorities and build on local capacities.

- NGOs enjoy higher operational flexibility as they are relatively free from bureaucratic structures and systems, and better able to respond and adapt quickly and easily.

- NGOs often work with and on behalf of most needy groups: the poorest and the most vulnerable.

Thus, the assistance extended by the civic society towards risk reduction in the built environment can be through policy development and advocacy, education and awareness raising, technical assistance and human resources for risk and vulnerability assessments and enhancing community participation into local construction activities.

\subsubsection{Private and corporate sector}

This category consists of privately owned profit-orientated business and industrial groups. In most societies, the private sector has been the driving force behind socioeconomic development (UN/ISDR, 2008). According to UN/ISDR, the private sector adversely suffers from the consequences of disasters and therefore it has a role to play in reducing disaster risk. In general, private sector has a role to play in moving towards sustainable development that incorporates an awareness of disaster risk (UNDP, 2004). In this context, the UN Global Compact, launched in 2000 to bring businesses together with UN agencies, labour, civil society and governments requests businesses to integrate disaster prevention into their decision-making.

Incidentally, there are various private and corporate sector institutions which have a direct interest in disaster risk reduction in the built environment. In particular, majority of the developers, consultants, contractors and sub contractors, banks and finance institutions that design, construct, maintain and finance the built environment can be categorised under this stakeholder group. They are the entities who are responsible for implementation of policies, regulations or guidelines including building codes and construction standards for disaster risk reduction in actual practice to minimise disaster vulnerabilities in the built environment.

\subsubsection{Academia and professional associations}

This group of stakeholders are universities, research organisations, and professional associations engaged in research, and training and development of individuals and organisations involved in disaster risk reduction. Academia and various professional associations are the prominent stakeholders in disaster risk reduction in the built environment for related education, training and research and development for built environment professionals and other workers, invention of methods and techniques for reconstruction and development of technical standards and guidelines for reconstruction.

Having explained the framework introduced for capacity development, the paper moves to its case study to analyse the capacity gaps that could be identified through literature. 


\section{CAPACITY GAPS IN DISASTER RISK REDUCTION - A CASE STUDY ON SRI LANKA}

\subsection{Disaster profile of Sri Lanka}

Sri Lanka is an island situated in the Indian Ocean, located to the south of the Indian subcontinent. Duryog Nivaran (2009) details the countries geographical characteristics and meteorological factors briefly as follows.

"Sri Lanka is separated from the Indian subcontinent by a trip of shallow water, the Palk Strait, which at its narrowest is about $40 \mathrm{~km}$ wide. It has the Gulf of Manner to its west, the Indian Ocean to its south and the Bay of Bengal to its east. With a total land area of 65,525 square kilometers inhabited by 19.5 million people, the country is among the most densely populated in the world, ranking 19th in the order of high density. Sir Lanka is mountainous in the central region and all rivers originate from the central hills and flow down to the sea. Sri Lanka has a tropical climate fed by two monsoons born in the Indian Ocean and two brief inter-monsoon periods. There is considerable variation in rainfall and evaporation as the topography changes from highlands to coastal plains."

Sri Lanka is prone to various natural disasters caused mainly by floods, cyclones, landslides, drought and coastal erosion with increasing instances of environmental pollution related hazards (Disaster Management Centre, 2005). Floods and landslides are more localised and seasonal whilst droughts and cyclones are more widespread and occasional (Duryog Nivaran, 2009). Table 1 details the most common disaster types in Sri Lanka. However, the devastation caused by the Indian Ocean tsunami of 2004 has highlighted that Sri Lanka is also vulnerable to low-frequency, high impact events which cause extensive damage and reverse years of development gains (Disaster Management Centre, 2005).

Table 1. Frequent disaster types in Sri Lanka (adopted from: Duryog Nivaran, 2009)

\begin{tabular}{|c|c|c|}
\hline Hazard & Description & Causes \\
\hline Floods & $\begin{array}{l}\text { Floods are an annual occurrence bringing tremendous } \\
\text { damage to life and livelihoods. Whilst the wet zone suffers } \\
\text { periodic river breaching the country's vast dry zone plains } \\
\text { are not spared calamitous flooding. }\end{array}$ & $\begin{array}{l}\text { - Heavy seasonal rainfall } \\
\text { - Deforestation } \\
\text { - Lack of flood protection schemes } \\
\text { - Unplanned development activities }\end{array}$ \\
\hline Landslides & $\begin{array}{l}\text { Landslides occur in areas that receive } 1000-4000 \mathrm{~mm} \text { of } \\
\text { annual rainfall. Eight of Sri Lanka`s } 25 \text { districts are prone } \\
\text { to landslides. Some } 12,000 \text { square kilometers of the country } \\
\text { are designated as vulnerable to landslides. }\end{array}$ & $\begin{array}{l}\text { - Heavy rainfall } \\
\text { - Geology } \\
\text { - Unsafe land use and construction } \\
\text { practices } \\
\text {-Deforestation }\end{array}$ \\
\hline Droughts & $\begin{array}{l}\text { Severe droughts are reported in Sri Lanka approximately } \\
\text { once a decade. Apart from severe droughts, there is a slow, } \\
\text { constant drought suffered by a large portion of the dry-zone } \\
\text { population. Each year, somewhere in Sri Lanka people face } \\
\text { droughts of short duration and local significance. }\end{array}$ & $\begin{array}{l}\text { - Inadequate rainfall } \\
\text { - Deforestation }\end{array}$ \\
\hline Cyclones & $\begin{array}{l}\text { Sri Lanka`s definition of a cyclone refers to wind speeds of } \\
\text { over } 118 \mathrm{~km} / \mathrm{h} \text {, whilst a cyclonic storm has wind speeds of } \\
62-117 \mathrm{~km} / \mathrm{h} \text {. Sri Lanka lies in the periphery of the tropical } \\
\text { cyclone belt and the impact of cyclones is lesser than on the } \\
\text { other nations in the region. Cyclonic storms occur mainly } \\
\text { during north-east monsoon conditions, the overwhelming } \\
\text { majority of these }(85 \%) \text { during the month of December. }\end{array}$ & $\begin{array}{l}\text { - Monsoon activity } \\
\text { - Severe weather changes in the Bay } \\
\text { of Bengal }\end{array}$ \\
\hline
\end{tabular}




\subsection{Capacity gaps}

As mentioned in an earlier section as well, capacity gaps in the field of disaster management in general are common to disaster risk reduction within the built environment as well. In this context, the following gaps identified in disaster risk reduction (DRR) in Sri Lanka (Chandradasa, 2008) can be related to the built environment as well.

- Laws and regulations which hinder speedy and smooth functioning of the DRM (disaster risk management) mechanism.

- Unavailability of necessary legal mandates for some of the major stakeholders for carrying out required DRR functions.

- Deficiencies in legislation for integration of DRR in all development projects.

- Problems in national level regulatory structure (eg: existence of more than one nodal ministry at national level to look after all phases of disaster management cycle).

- Inadequate funds for DRR activities.

- Difficulties in resettling people living in identified high risk disaster prone areas due to social and political issues.

- Deficiencies in the EIA process which lead to an inadequate attention towards disaster impacts.

- Lack of community participation in DRR activities and community ignorance (eg: even with threat to their lives some communities do not heed to the alerts and resist evacuations).

- Difficulties in sustaining the interest of trained volunteers at village level.

- Problems in early warning systems.

Complying with most of the points in the aforementioned list of gaps, Duryog Nivaran (2009) identifies some main gaps in the disaster management system in Sri Lanka such as poor coordination between various agencies; lack of training and education for officials and the public which results in poor awareness; absence of proper warning systems; inadequate emphasis on disaster preparedness; lack of finances and delays in relief distribution.

It was emphasised in an earlier section that the building codes, land-use planning policies and construction standards are important in improving the design and construction activities within the built environment. However, according to Gunaratnam (cited DMC-SL, 2010), the safe building guidelines have not been practiced properly owing to various gaps within the system in Sri Lanka in spite of they have been in existence for decades. Further, it has been pointed out that landslides often take place in Sri Lanka in its mountainous regions and in urban areas in particular, due to wrong practices, unavailability of retaining structures, improper cutting and filling operations etc. (Disaster Management Centre, 2005).

Incidentally, the tsunami on $26^{\text {th }}$ December 2004 drew the attention of the government and the society towards many capacity gaps in the disaster management system of Sri Lanka. According to (Jayawardena, 2006), the massive destruction caused by the tsunami reconfirmed the need for multi-sectoral, inter-institutional and multi-disciplinary approaches to manage disaster risks in Sri Lanka. The findings of a study on reconstruction capacity gaps in Sri Lanka following the 2004 Tsunami highlight several capacity gaps that have hindered reconstruction efforts in the built environment after the tsunami (Haigh et al., 2009). The capacity gaps are highlighted under five major themes as national and local government; nonstate actors and the private sector; communities; the policy environment; and, human resource development in the study and following list elaborates the major gaps among them.

- Inexperience and lack of capacity at national and local government level;

- lack of plans for post-disaster response and coordination, 
- inadequacy of ad-hoc structures introduced following the Tsunami,

- confusion over responsibility,

- involvement of too many government agencies,

- lack of leadership and direction,

- poor horizontal communication between national and regional government,

- inappropriate land to build upon and poor coordination between housing and required infrastructure,

- lack of basic project management skills,

- poor management and coordination capacities of government entities established for post Tsunami recovery

- Lack of transparency, inadequate supervision of local contractors, one-sided contracts and competition between agencies in donor driven schemes;

- Deficiencies in core trades;

- Lack of capacity within the private and non state actors to handle large scale reconstruction.

In this context, the subsequent section focuses on discussing the possible remedies for aforementioned capacity gaps.

\subsection{Discussion}

According to the earlier sections, it is evident that there are many capacity gaps related to disaster risk reduction in the built environment in Sri Lanka. Problems in the regulatory structure, deficiencies in necessary laws and regulations including problems in their implementation, and lack of required resources and skills are prominent among them. However, the Sri Lanka Disaster Management Act No 13 of 2005 was enacted providing a solid legislative and institutional arrangement for Disaster Risk Management in Sri Lanka after the 2004 tsunami followed by establishing the Disaster Management Centre and a separate ministry for disaster management (Jayawardena, 2006). Incidentally, the following activities which have been put forward by the policy document, "Towards a safer Sri Lanka- Road Map for disaster risk management" published by the Disaster Management Centre in 2005 focus on bridging the aforementioned gaps in the built environment.

- Review and revise the building approval procedures adopted by local government agencies to reduce the impact of natural disaster events.

- Integrate disaster risk mitigation into development processes through disaster mitigation plans, and specific allocation for mitigation in all development budgets.

- Provide training and awareness raising on integrating DRM into development plans.

- Mitigate impact of landslides and reduce risk through improvements and recommendations for structural mitigation.

- Protect against and control floods through improvements and new protection systems.

- Reduce disaster risk in all physical planning processes by integrating DRR in decision making on national land use and physical planning policies.

- Protect against storm surges/ sea/ coastal flooding through green belt and incorporation of disaster risk considerations in coastal zone management;

- Increase disaster resilience in housing and other critical infrastructure through revisions in building codes and by laws;

- Reduce dam-related hazard risks through appropriate dam safety regulations.

- Undertake research activities through universities and other institutes to arrive at the most suitable methods of construction in disaster prone areas. 
However, Nateghi-A (2000) emphasises that disaster-resistant building codes are, unlikely to result in resistant buildings unless the engineers who have to implement the code accept its importance and endorse its use, understand the code and the design criteria required of them and unless the code is fully enforced by authorities checking and penalising designs that do not comply. Thus, land use planning, construction approval processes and construction procedures need to be supported by the construction professionals and authorities in a way that they meet their desired goal. Apropos, Chandradasa (2008) suggests amendments to the prevailing disaster management act to enable a speedy and smooth functioning of the disaster risk management mechanism.

In order to address the issues in training, education and awareness building related to disaster risk reduction in the built environment, several activities have been proposed in Sri Lanka. In this context, the necessity of including "Building Guidelines for Infrastructure at Risk of Natural Disasters" in to the tertiary level curriculum has recently been pointed out as an important need (Gunaratnam cited DMC-SL, 2010). Further, to fulfil a long felt need in the curriculum of vocational training and higher education institutions in the country, the Disaster Management Centre of Sri Lanka in collaboration with the country's UNDP Disaster Risk Management Programme has commenced working towards incorporating Disaster Risk Reduction concerns into the Civil Engineering curriculum of Technical Colleges. After the 2004 tsunami experience, almost all the Universities in the country have increased their interest on conducting research and development, providing policy assistance, carrying out data collection, storage and dissemination, and conducting continuing professional development courses in relation to disaster management (Jayawardena, 2006).

Similarly, the community involvement in disaster risk reduction activities is attempted to increase through various programmes such as community based organisations and community-driven post-disaster reconstruction (Homeless International, 2010; Asian Disaster Preparedness Centre, 2003). The aforementioned factors indicate the major efforts towards minimising key problems related to disaster risk reduction in the built environment in Sri Lanka. However, there are number of issues in bridging the capacity gaps which occur due to various political, social and cultural reasons.

\section{CONCLUSIONS}

Developing necessary capacities are important to reduce risk of disasters and possible disaster damages in the built environment. However, capacity development in this context is a complicated process which needs to consider various stakeholders. In this regard, the framework introduced in the paper provides a comprehensive foundation for capacity development since it identifies capacity development fragmenting into four different stages against six major stakeholder groups in the built environment. As the first stage of the framework suggests, identifying and analysing existing capacity gaps is significant since it leads to recognise the areas that need to be developed.

As the case study on Sri Lanka suggests, capacity gaps in the field of disaster management in general are common to disaster mitigation and reconstruction within the built environment as well. However, problems in the regulatory structure, deficiencies in necessary laws and regulations including problems in their implementation, and lack of required resources and skills are the major capacity gaps related to disaster risk reduction in the built environment in Sri Lanka. Integration of disaster risk reduction into construction activities and new developments through adhering to regulations is not conducted as required 
converting the country's built environment to a more vulnerable status to disasters. Literature highlighted the loopholes in land use policies, building approval process, implementation of safe building regulations and practice of correct construction activities in the country. Further, lack of community involvement in mitigation and reconstruction activities, deficiencies in necessary skills and resources for safe and correct practices within the built environment and, lack of awareness on mitigation measures and reconstruction efforts are prevailing capacity gaps in the country.

\section{REFERENCES}

Asian Disaster Preparedness Center (2003) Community-based disaster risk reduction in Central Sri Lanka, Safer Cities 5, Asian Disaster Preparedness Center (ADPC), Thailand.

Benson, C., Twigg, J. and Rossetto, T. (2007) Tools for mainstreaming disaster risk reduction: guidance notes for development organisations, Switzerland: ProVention Consortium.

Bolger, J. (2000) Capacity development: why, what and how, Capacity Development-Occasional Series, $1(1)$, pp. 1-8.

Bosher, L., Dainty, A., Carrillo, P. and Glass, J. (2007a) Built-in resilience to disasters: a preemptive approach, Engineering, Construction and Architectural Management, 14(5), pp. 434446. doi:10.1108/09699980710780746

Bosher, L., Dainty, A., Carrillo, P., Glass, J. and Price, A. (2007b) Integrating disaster risk into construction: a UK perspective, Building Research and Information, 35(2), pp. 163-177. doi:10.1080/09613210600979848

Bourne, L. (2007) Rethinking construction stakeholder management in the construction industry. [Online] Available at: http://www.mosaicprojects.com.au/PDF_Papers/P049_Rethinking_Construction.pdf [accessed 15 April 2010]

Chandradasa, U. W. L. (2008) Disaster risk reduction for safer Sri Lanka, Asian Conference on Disaster Reduction 2008, 12-14 November 2008, Bali, Republic of Indonesia.

Disaster Management Centre (2005) Towards a safer Sri Lanka: road map for disaster risk management, Disaster Management Centre Ministry of Disaster Management, Government of Sri Lanka. ISBN: 9551393007

DMC-SL (2010) Safe building guidelines integrated into formal education. [Online] Disaster Management Centre of Sri Lanka. Available at: http://www.dmc.gov.lk/index_english.htm [accessed 10 January 2010]

Duque, P. P. (2005) Disaster management and critical issues on disaster risk reduction in the Philippines, International Workshop on Emergency Response and Rescue, 31 October - 1 November 2005, National Fire Agency, Ministry of Interior, R.O.C.

Duryog Nivaran (2009) Disaster profile - Sri Lanka. [Online] Duryog Nivaran, Sri Lanka. Available at: http://www.duryognivaran.org/sri.php [accessed 12 January 2010]

El-Masri, S. and Tipple, G. (2002) Natural disaster, mitigation and sustainability: the case of developing countries, International Planning Studies, 7(2), pp. 157-175. doi:10.1080/13563470220132236

Geis, D. E. (2000) By design: the disaster resistant and quality-of-life community, Natural Hazards Review, 1(3), pp. 151-160. doi:10.1061/(ASCE)1527-6988(2000)1:3(151)

Ginige, K. N., Amaratunga, R. D. G. and Haigh, R. (2009) Enhancing capacities for disaster mitigation and reconstruction in the Built Environment, CIB Joint International Symposium 2009, 27th-30th September 2009, Dubrovnik, Croatia.

Gupta, M. and Sharma, A. (2006) Compounded loss: the post tsunami recovery experience of Indian island communities, Disaster Prevention and Management, 15(1), pp. 67-78. doi:10.1108/09653560610654248

Haigh, R., Amaratunga, D., Keraminiyage, K. and Jayasena, S. (2009) Reconstruction capacity gaps in Sri Lanka following the 2004 Tsunami, Submitted to Disaster Prevention and Management.

Homeless International (2010) Project: Post-disaster reconstruction and disaster preparedness. [Online] Homeless International. Available at: http://www.homeless-international.org/ standard_1.aspx?id=1:30586\&id=0:427\&id=0:2 77\&id=0:262 [accessed 12 January 2010]

Honadle, B. W. (1981) A Capacity-building framework: a search for concept and purpose, 
Public Administration Review, 41(5), pp. 575580. doi:10.2307/976270

Iriye, A. (2002) Global community: the role of international organisations in the making of the contemporary world. California: University of California Press.

Jayaraj, A. (2006) Post disaster reconstruction experiences in Andhra Pradesh in India. In: IF Research Group (ed.), International conference on post-disaster reconstruction. Available at: http://www.grif.umontreal.ca/pages/i-rec\%20 papers/annie.pdf

Jayawardena, A. K. W. (2006) Disaster mitigation initiatives in Sri Lanka. [Online] Available at: http://management.kochi-tech.ac.jp/PDF/ IWPM/IWPM_Jayawardane.pdf [accessed 5 October 2008]

Laverack, G. (2005) Evaluating community capacity: visual representation and interpretation, Community Development Journal, 41(3), pp. 266-276. doi:10.1093/cdj/bsi047

Lawther, M. L. (2009) Community involvement in post disaster re-construction - case study of the British Red Cross Maldives recovery programme, International Journal of Strategic Property Management, 13(2), pp. 153-169. doi:10.3846/1648-715X.2009.13.153-169

Lloyd-Jones, T. (2006) Mind the Gap! Post disaster reconstruction and the transition from humanitarian relief. UK: Royal Institution of Chartered Surveyors.

Lusthaus, C., Adrien, M-H. and Perstinger, M. (1999) Capacity development: definitions, issues and implications for planning, monitoring and evaluation, Universalia, Universalia Occassional Paper, No. 35, pp.1-21.

Mileti, D. S. (1999) Disasters by design. In: Britton, N. R. (ed.), Proceedings of a conference sponsored by Aon Group Australia Limited on The changing risk landscape: implications for insurance risk management. Available at: http://www.aonline-aon.com/public/intelligence/ disasters_by_design.pdf
Nateghi-A, F. (2000) Disaster mitigation strategies in Tehran, Iran, Disaster Prevention and Management, 9(3), pp. 205-211. doi:10.1108/09653560010335194

Newcombe, R. (2003) From client to project stakeholders: a stakeholder mapping approach, Construction Management and Economics, 21(8), pp. 841848. doi:10.1080/0144619032000072137

Nuseibeh, B. and Easterbrook, S. (2000) Requirements Engineering: A Roadmap. ICSE-Future of SE Track.

Owen, D. and Dumashie, D. (2007) Built environment professional's contribution to major disaster management, Strategic Integration of Surveying Services, FIG Working Week, 13-17 May 2007, Hong Kong.

Pardasani, M. (2006) Tsunami reconstruction and redevelopment in the Maldives, Disaster Prevention and Management, 15(1), pp. 79-91. doi:10.1108/09653560610654257

Siriwardena, N., Haigh, R. and Ingirige, M. J. B. (2009) Identifying and classifying stakeholders of post disaster reconstruction projects in Sri Lanka, Salford Postgraduate Research Conference-2009, 7-8 May 2009, The University of Salford, Salford, UK.

UN/ISDR (2009) 2009 UN/ISDR terminology on disaster risk reduction. Geneva: United $\mathrm{Na}$ tions International Strategy for Disaster Reduction (UN/ISDR).

UN/ISDR (2008) Private sector activities in disaster risk reduction-good practices and lessons learned. Geneva: United Nations International Strategy for Disaster Reduction (UN/ISDR).

UNDP (2004) Reducing disaster risk: a challenge for development. Geneva: United Nations Development Programme (UNDP).

UNDP (2008) Capacity assessment practice note. New York: United Nations Development Programme (UNDP).

Ye, J., Hassan, T., Carter, C. and Kemp, L. (2009) Stakeholders' requirements analysis for a demand driven construction industry, Journal of Information Technology in Construction (ITcon), 14, pp. 629-641. 


\section{SANTRAUKA}

\section{GEBE்JIMO MAŽINTI NELAIMIŲ KELIAMĄ RIZIKĄ UŽSTATYTOJE APLINKOJE UGDYMAS: GEBĖJIMŲ ANALIZĖ ŠRI LANKOJE}

\section{Kanchana GINIGE, Dilanthi AMARATUNGA, Richard HAIGH}

Šiame darbe pristatoma sistema, leidžianti ugdyti gebėjimą mažinti nelaimių keliamą riziką užstatytoje aplinkoje. Sistema sudaryta vykdant nuolatini tyrima, kuriuo siekiama didinti užstatytoje aplinkoje veikiančių individų ir institucijų gebèjimus, idant nelaimių keliamos rizikos mažinimas darniai atitiktų jo misiją ir tikslus. Sistema pateikiama kaip matrica, kurią sudaro keturi gebejjimų ugdymo etapai ir šešios užstatytoje aplinkoje veikiančios interesu grupès. Etapai ir interesu grupės buvo nustatytos apklausiant ekspertus ir išsamiai apžvelgiant literatūra. Keturi etapai pavadinti „Analize““, „Kūrimas“, „Panaudojimas“ ir „Išlaikymas“. Tolesnèse šio darbo dalyse aptariamas pirmasis etapas „Analizë“ ir pateikiamos kelios pradinès tyrimo išvados. Analize siekiama užfiksuoti atitinkamame kontekste esančias gebėjimu spragas, kad būtų aišku, kuriuos gebẻjimus reikia ugdyti. Tyrime apžvelgiama literatūra apie Šri Lanką ir aptariamos tokios gebejjimu spragos. Nustatyta, kad pagrindinès šalies gebėjimu spragos yra šios: problemos reglamentavimo struktūroje, būtinu ịstatymų ir reglamentų trūkumai, i̇skaitant jų igyvendinimo problemas, ir reikiamų išteklių bei igūdžiu stoka. 